\title{
Goussia hyperolisi n. sp.: a coccidian infection in reed frog Hyperolis viridiflavus tadpoles which expires towards metamorphosis
}

\author{
I. Paperna ${ }^{1, *}$, W. Ogara ${ }^{2}$, M. Schein ${ }^{1}$ \\ ${ }^{1}$ Department of Animal Sciences, Faculty of Agriculture of the Hebrew University of Jerusalem, Rehovot 76-100, Israel \\ ${ }^{2}$ Department of Public Health, Pharmacology and Toxicology, Faculty of Veterinary Medicine, POB 29053, Kabete, Kenya
}

\begin{abstract}
Goussia hyperolisi $\mathrm{n}$. sp. is described from the guts of Hyperolis viridiflavus tadpoles taken from a fish pond at Sagana, Kenya. Infection expired as metamorphosis approached. No infection could be found in post-metamorphosed and older frogs. Infected tissues were studied by light and electron microscopy. Endogenous stages, meronts and gamonts were in cells of the gut epithelium within a parasitophorous vacuole with folded rims. In the macrogamonts, small bodies with a dense core were the only structures reminiscent of wall-forming bodies. The wall membranes which formed following zygote formation detached and merged with the parasitophorous vacuole wall to form the oocyst wall. During the regression of the infection, the one or several sporulated oocysts in the infected host cell, an epithelial or intraepithelial leukocyte, became embedded in a multilaminated matrix, the yellow body, and were eventuailly destroyed.
\end{abstract}

KEY WORDS: Goussia hyperolisi n. sp. Coccidia. Hyperolis viridiflavus Kenya Tadpoles Yellow bodies

\section{INTRODUCTION}

Many named species of Eimeria described from anurans have soft-walled oocysts which sporulate within their host's gut epithelial tissue (Paperna 1995a, Paperna $\&$ Lainson 1995). The sporocysts of these species open via longitudinal sutures rather than having an apical opening plugged with a stieda body. These features are shared with many piscine coccidia included in the genus Goussia Labbe, 1896 (Paperna 1995b). This led Molnar (1995) to place E. neglecta Nöller, 1920, which he redescribed, into the genus Goussia. The unique form of development of anuran coccidia which segregates them from the eimerians of the higher vertebrate taxa had already been noticed by Laveran \& Mesnil in 1902, but their proposal for a separate subgenus Paracoccidium for the anuran species was ignored. To date most of the described species of anuran eimeriid coccidia have been reported from metamorphosed anurans (Upton \& McAllister 1988). From tadpoles only Goussia neglecta has been described (Nöller 1920, Molnar 1995). In this communi-

•E-mail: solomon@agri.huji.ac.il cation, we present the results of a light and electron microscopic study of another eimeriid coccidium of the genus Goussia from the digestive tract of tadpoles of the reed frog Hyperolis viridiflavus (Dumeril \& Bibron) from Sagana fish ponds in Central Kenya.

\section{MATERIALS AND METHODS}

After finding coccidial infection in reed frog Hyperolis viridiflavus tadpoles collected in a fish pond on the Sagana farm in Central Kenya, more tadpoles as well as adult reed frogs were collected from the same habitat and brought to the laboratory. There, within 1 to $14 \mathrm{~d}$ after collection the animals were sacrificed (by anaesthesia using chloroform) and examined for infection.

Prepared intestinal smears were air dried and Giemsa stained after fixation in absolute methanol. Samples of the same infected tissues were fixed in Neutral Buffered Formalin for histology. Fixed tissue, after dehydration in graded ethanols, was embedded in glycol-methacrylate medium (GMA of Agar Comp., UK). Sections, 3 to $4 \mu \mathrm{m}$ thick, were cut with a glass knife on a Sorval JB4 microtome and stained with 
Table 1 Autopsy results of Hyperolis viridiflavus tadpoles (T), post-metamorphosis (Fm) and adult frogs (Fa). Neg.: negative for Goussia hyperolisi n. sp. infection

\begin{tabular}{|c|c|c|c|c|c|c|}
\hline Date & Stage & Merog./Gamonts & Oocysts & Oo+spor & Yellow bodies & Neg. \\
\hline $1 \mathrm{Sep}$ & $\mathrm{T}_{;} 4$ legs & & ++ & ++ & & \\
\hline 23 Sep & $T_{;} 2$ legs & & + & ++++ & ++ & \\
\hline 23 Sep & T; 0 legs & & & & & Neg. \\
\hline 23 Sep & $T ; 4$ legs & & & & & Neg. \\
\hline 23 Sep & $T: 4$ legs & & & & & Neg. \\
\hline $23 \mathrm{Sep}$ & $T ; 4$ legs & & & & + & \\
\hline 23 Sep & $T_{;} 4$ legs & & ++ & ++++ & +++ & \\
\hline 23 Sep & $T_{i} 4$ legs & & & + & t+ & \\
\hline $23 \mathrm{Sep}$ & $\mathrm{T} ; 2$ legs & + & + & ++ & & \\
\hline $23 \mathrm{Sep}$ & $\mathrm{T}_{i} 0$ legs & & & ++ & + & \\
\hline 23 Sep & $T_{i} 0$ legs & & & & & Neg. \\
\hline $\begin{array}{l}10 \text { Oct } \\
\text { (Coll. } 23 \text { Sep) }\end{array}$ & $\begin{array}{l}2 \text { legs } \\
\text { (stunted) }\end{array}$ & + & + & ++ & & \\
\hline $\begin{array}{l}10 \text { Oct } \\
\text { (Coll. } 23 \mathrm{Sep} \text { ) }\end{array}$ & $\begin{array}{l}0 \text { legs } \\
\text { (stunted) }\end{array}$ & & & + & + & \\
\hline $23 \mathrm{Sep}$ & $\mathrm{Fm}$ & & & & & Neg. \\
\hline $23 \mathrm{Sen}$ & $\mathrm{Fm}$ & & & & + & Neg. \\
\hline $23 \mathrm{Sep}$ & $\mathrm{Fm}$ & & & & & Neg. \\
\hline $23 \mathrm{Sep}$ & $\mathrm{Fm}$ & & & & & Neg. \\
\hline $10 \mathrm{Oct}$ & $\mathrm{Fa} ; 11$ spe & (feces) & & & & Neg. \\
\hline
\end{tabular}

Meyer's haemalum-eosin (MHE). For electron microscopy, tissues were fixed in $2.5 \%$ cacodylate $10.1 \mathrm{M}$ $\mathrm{pH}$ 7.4) buffered glutaraldehyde for $24 \mathrm{~h}$ at $4^{\circ} \mathrm{C}$, repeatedly rinsed in cacodylate buffer, post-fixed in $1 \%$ osmium tetroxide in the same buffer for $1 \mathrm{~h}$, rinsed in the buffer and in distilled water, stained en bloc with aqueous uranyl acetate for $3 \mathrm{~h}$, rinsed in distilled water, dehydrated in ascending ethanol concentrations and embedded in Agar $100^{(3)}$ (Agar Comp.). Thin sections were cut on a Reichert 'Ultracut' with a diamond knife stained on grid with uranyl acetate and lead citrate, and examined in a Jeol 100CX transmission electron microscope (TEM). The means of measurements are given with ( \pm ) standard deviation and number measured (n).

\section{RESULTS}

Reed frog tadpoles from Sagana ponds were first examined and found to be infected on September 1 , 1994. Both tadpoles and adult frogs were subsequently collected on September 23 of the same year. In the first and second collections most tadpoles had 4 legs, and only a few were still at the 2 or no-leg stage. Of the 10 examined tadpoles 6 revealed coccidian infections in various stages of regression, consisting mostly of sporulated oocysts, in part located inside yellow bodies. The gut epithelium also contained many yellow bodies without any remains of parasites. Two tadpoles, one with 2 legs and one without legs, left in the laboratory for a further $17 \mathrm{~d}$ in a $1-1$ dish in tap water at an ambient temperature of 26 to $28^{\circ} \mathrm{C}$ failed to develop to metamorphosis. When sacrificed, these tadpoles demonstrated a similarly regressed infection consisting predominantly of sporulating oocysts, accompanied by many yellow bodies. However, they also revealed a very small number of early meronts for gamonts). Four post-metamorphosis frogs and feces collected from 11 additional adult specimens retained in captivity were negative (Table 1).

\section{Electron microscopic observations}

Non-differentiated, $4.5-5.2 \times 2.3-3.6 \mu \mathrm{m}$ meronts (Fig. 1) and a formation of merozoites $9.5 \times 3.9 \mu \mathrm{m}$ in

Figs. 1 to 6. TEM images of Coussia hyperolisi n. sp. from Hyperolis viridiflavus tadpoles. Fig. 1. Meront $(\times 12600)$. n: parasite nucleus; di: dense inclusions. Fig. 2. Formation of merozoites extending from the meront residuum (Rd); arrows: mitochondrion $(\times 11500)$ a: apical complex; m: micronemes; $r$ rhoptries. Fig. 3. Enlargement of the merozoite's anterior portion $(\times 16200)$ t: duct-like formation. Fig. 4. Macrogamont $(\times 12900)$. nu: nucleolus; cn: canaliculi; ad: adnuclear inclusions; wb (and arrows) wall-forming-body-like organelles. Fig. 5. Zygote or early oocyst with detached wall, still enclosed parasitophorous vacuole by (PV) with intravacuolar folds (PV wall: pw) $(\times 11300)$. Fig. 6. Young oocyst with its envelope adhering to the PV wall ( $\times 7800)$. hn: host-cell nucleus; wp: merged oocyst wall 


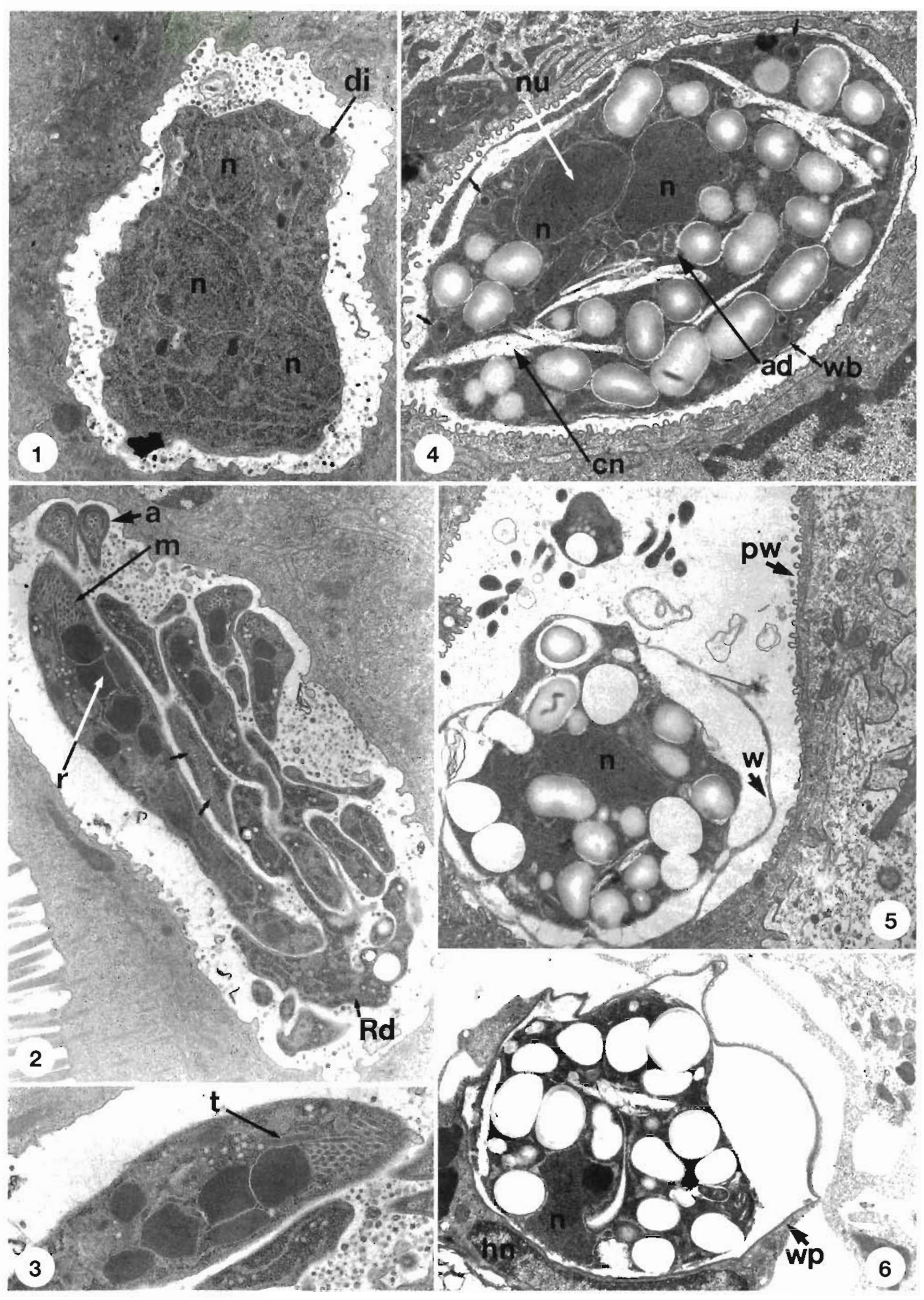


size (Fig. 2) were found located in cells of the gut epithelium between the nucleus and the brush border within a parasitophorous vacuolc (PV) with wavy to folded rims, fringed with many intravacuolar folds and filled with globular debris. Meronts were bound by a single membrane. Their cytoplasm contained extensive endoplasmic reticulum (ER), mitochondria and some electron-dense inclusions (Fig. 1). The very elongated $7-8 \mu \mathrm{m}$ long merozoites were still connected to a meront residue and were bound by a pellicle. The conoid and the apical ring were detectable in the tips of some merozoites (Fig. 2). Micronemes filled the merozoite's anterior end and several exceptionally large rhoptries filled the pronuclear zone; the latter are connected through duct-like formations to the apical region (Fig. 3). The cytoplasm was filled with very small amylopectin granules. In some, an elongate mitochondrion was traced. The meront's residuum contained amylopectin granules, of the same size as in the merozoites, and a few lipid vacuoles (Fig. 2).

The 7-9 $\times 4-5 \mu \mathrm{m}$ macrogamonts (Fig. 4) were lodged in a PV with a wavy wall and intravacuolar folds. Superimposed on this wall was a seemingly peeling and fractured (due to processing?) secondary membrane. Their condensed cytoplasm contained 3 bodies of nucleolemma-bound nucleoplasm, which seemed to be segments of a lobed nucleus. One segment contained a conspicuous nucleolus. The cytoplasm also contained several conspicuously large canaliculi, a network of ER, variable numbers of amylopectin granules, inclusions with contents similar in density to that of the cytoplasm, adnuclear organelles and a few small wallforming-body-like organelles with high-density cores.

Later stage macrogamonts (zygotes) and oocysts demonstrated variable degrees of processing damage, which appeared to result from decreased permeability to fixatives or embedding media. The late-stage macrogamonts or early-stage oocysts became enclosed in an additional, thickened 44-64 nm thick membrane (Fig. 5) which subsequently adhered to the rims of the PV to become the oocyst wall (Fig. 6). Host cells of $7-9 \times$ 6-8 $\mu \mathrm{m}$ oocysts demonstrated progressive cytoplasmic degradation, either becoming homogeneously dense or breaking into a multilaminate matrix (Fig. 7). Host cells with one to several variable-stage oocysts or their residues became rounded and separated from the sur- rounding tissue. The rims of such cells had pointed processes reminiscent of those seen on the surface of leukocytes. The cytoplasm was evidently progressively degenerating, becoming filled with electron-dense inclusions (lysosomes), and the start of multilamination could be seen at the rims of the oocyst-containing PVs (Figs. 8 \& 9). Sporocysts, in the early stage and already with sporozoites, were contained within their host cell inside a large body of degenerated cytoplasm (Fig. 10). Sporocysts were enclosed within a double-layer 77-85 $\mathrm{nm}$ thick wall with distinct longitudinal sutures. The sporocyst cytoplasm was filled with amylopectin granules and lipid vacuoles at a ratio of 2:1. The sporocyst residuum gradually disintegrated and disappeared once sporozoite differentiation was completed (Figs. 11 \& 12). Early-stage sporozoites revealed an apical complex accompanied by numerous micronemes as well as a fibrillar, tubular structure (which might be connected to the rhoptries complex?), a nucleus and dense aggregates of ribosomes. Neither refractile nor crystalloid bodies could be identified in the newly formed sporozoites (Figs. 11 to 13). The walls of the sporocysts hardened toward the completion of sporulation, which resulted in their further distortion due to their resistance to fixation and processing. Aged sporozoites within the hard-walled sporocysts contained a fair number of amylopectin granules. Other organelles could only be traced with difficulty; a large electron-dense body was tentatively identified as a refractile body (Figs. 14 to 16).

Changes in the host-cell cytoplasm first occurred around the PV, as evidenced by the formation of an increasingly thick layer of multilaminated material (Figs. 11 to 13). Sporocysts with their sporozoites ultimately disintegrated. The large body of seemingly necrotic substance remaining within the hypertrophied host cell contained very variable consistencies, incorporating remains of defunct sporocysts as well. The fine structural image of this material indicated a blend of vacuoles and electron-dense bodies, or multilaminated electron-dense matrix or both (Figs. 17 \& 18). All stages of the sporulation process before the formation of yellow bodies, which were identified from light microscopically examined material (Figs. 19 to 22), were identified from TEM images, except for the final accumulation of the lipofuscin (ceroid)-type material in the yellow body (Figs. $22 \& 23$ )

Figs. 7 to 10. TEM images of Goussia hyperolisi n. sp. from. Hyperolis viridiflavus tadpoles. Fig. 7. Host cells infected with a zygote or early oocyst $(\mathrm{O})$ demonstrating extensive degenerative changes: homogenously dense ( $\bar{Y} \mathrm{~d}$ ) and multilaminated cytoplasm (M) $(\times 6800)$. hn: host-cell nucleus. Figs. 8 \& 9 . Young oocysts $(O)$ and their residues (Or) inside a seemingly leukocytic, detached cell with lysosomes (L) and with surface processes, seen also in an adjacent noninfected cell (IL) ( $\times 4000 \& \times 5100)$. Fig. 10. Host cell almost completely occupied by multilaminated matrix yellow body ( $Y$ ) containing sporulated oocysts (So); remaining intact cytoplasm contains lysosomes (L) ( $\times 4300)$ 


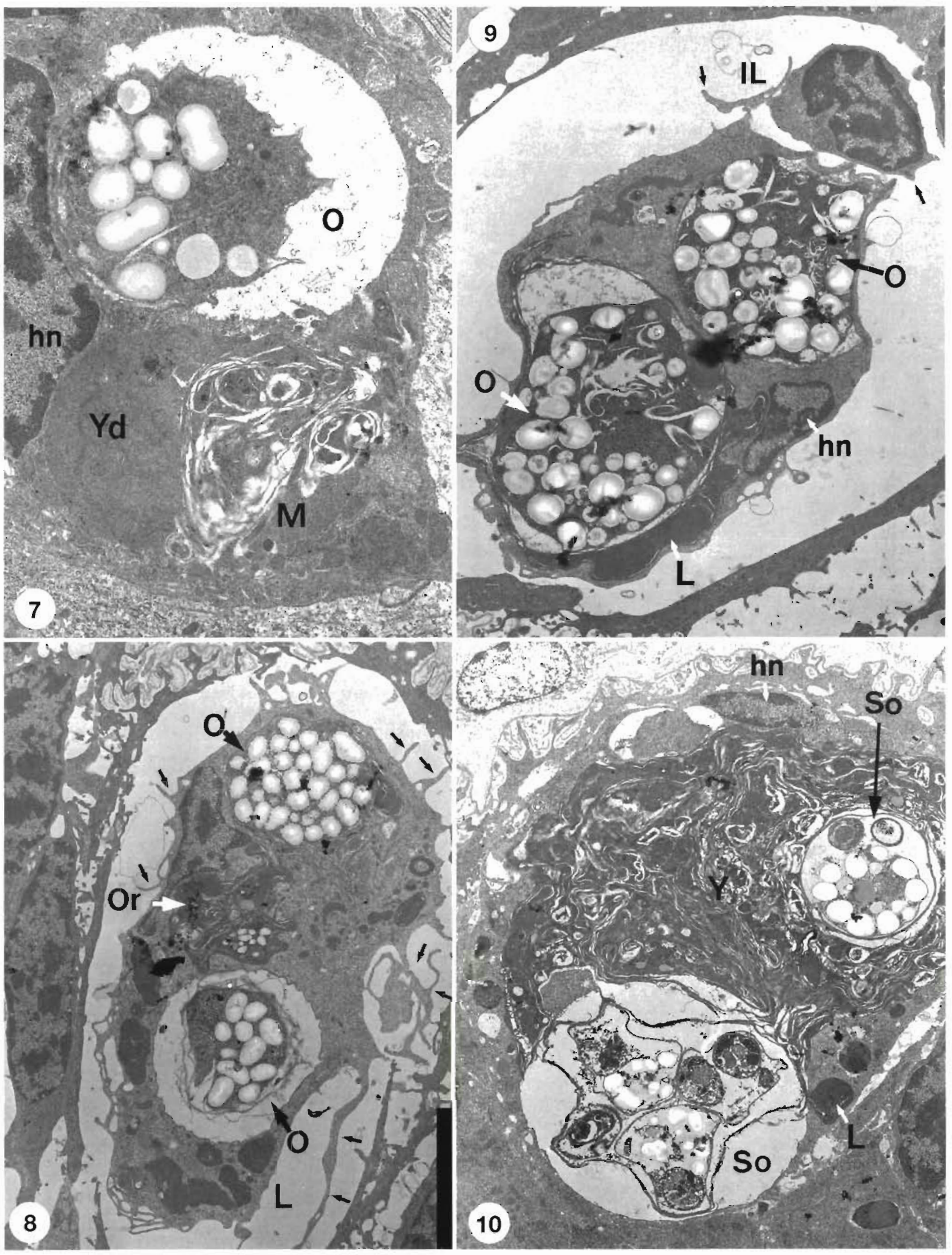




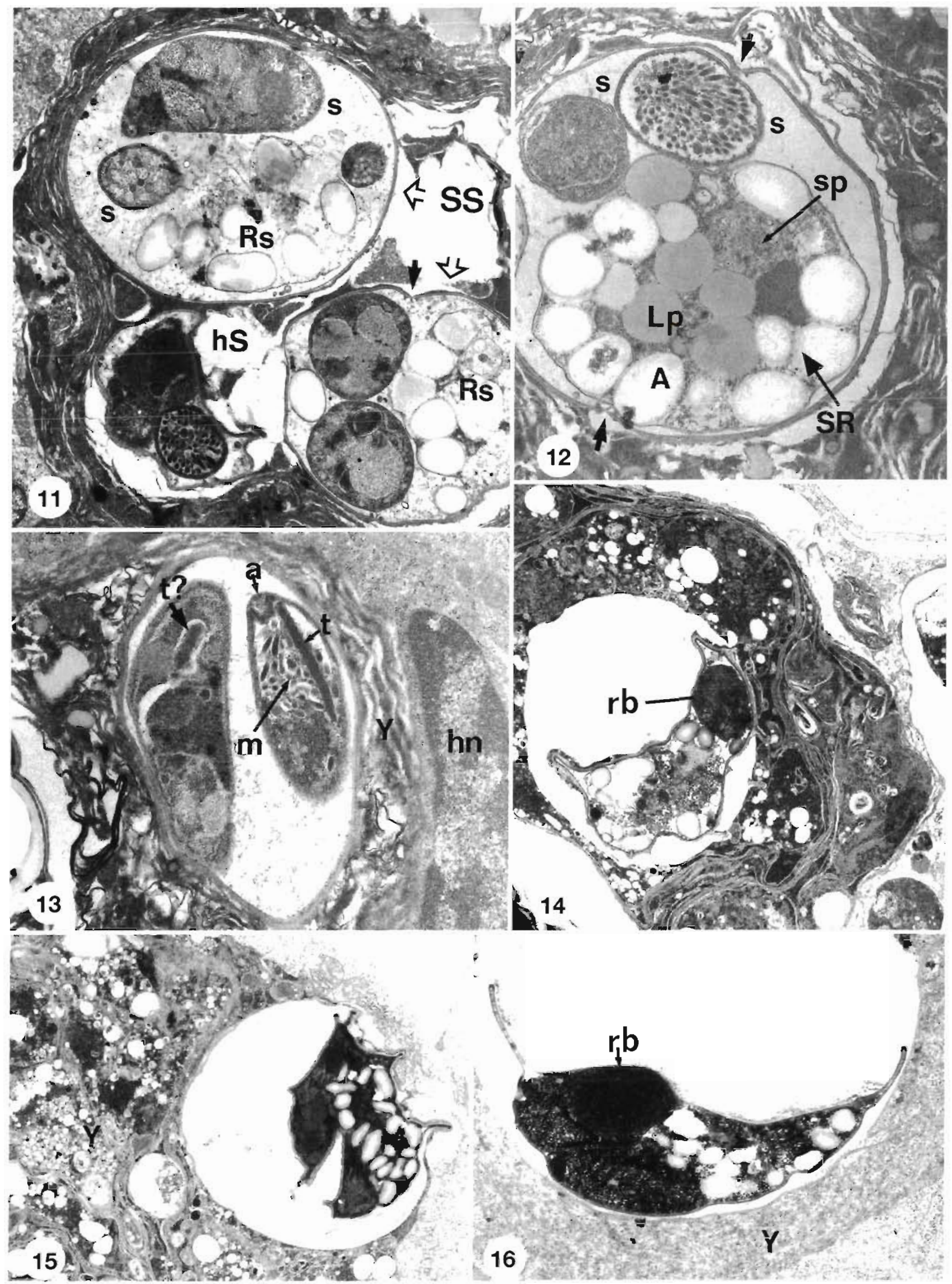


Figs. 11 to 16. TEM images of Goussia hyperolisi n. sp. from Hyperolis viridiflavus tadpoles. Fig. 11. Oocysts inside a yellow body demonstrating sporocysts at various stages of sporulation: soft-walled sporocysts (SS) with already formed sporozoites (s), disintegrating sporocyst residuum (Rs) and hard-walled sporocyst (hS). Arrow points to suture $(\times 9200)$. Fig. 12. Higher magnification of differentiating sporocyst with sporozoites (s) emerging from a residuum (SR) of cytoplasm (sp) rich in lipid vacuoles (Lp) as well as amylopectin granules (A). Arrows point on the sutures $(\times 12900)$. Fig. 13. Two sporozoites inside a sporocyst revealing a pical complex (a), a tube (connected to rhoptries) ( $\mathrm{t}$ ) and micronemes (m); hn: host cell nucleus; $Y$ - yellow body $(\times 15900)$. Figs. 14 to 16 . Images of yellow body $(\mathrm{Y})$ including hard-walled sporocysts containing sporozoites; rb: a presumed refractile body $(\times 8000, \times 8400 \& \times 13800)$

\section{Taxonomy}

Goussia hyperolisi n. sp.

Type host: Hyperolis viridiflavus (Dumeril \& Bibron), tadpoles.

Type locality: Sagana fish ponds, Kenya.

Type material: Syntypes, Giemsa-stained slides in the Israel National Collection of Natural History (c/o I. Paperna).

\section{Description}

Early oocysts in fresh impressions from the gut were $7.7 \pm 1.0(7.0-9.8) \mu \mathrm{m}(\mathrm{n}=11)$ and sporoblasts $9.45 \pm$
$0.91(8.4-10.6) \mu \mathrm{m}(\mathrm{n}=6)$ in diameter. Mature $7.22 \pm$ $0.25 \times 4.92 \pm 1.07(5.6-7.7 \times 4.2-5.6) \mu \mathrm{m}(\mathrm{n}=8)$ sporocysts were colorless, and in addition to the $7 \times 1.4-2 \mu \mathrm{m}$ sporozoites contained a $4.2-5.6 \times 2.8 \mu$ m residual body (Figs. 24, 25 \& 26). In Giemsa-stained smears from the gut, round, amylopectin-loaded oocysts were $7.74 \pm 0.56$ $\times 7.04 \pm 0.44(7-8.4 \times 6.3-7.7) \mu \mathrm{m}(\mathrm{n}=6)$. Sporoblasts with 2 or 4 nuclei were $8.4-13.3 \times 7.7-11.2 \mu \mathrm{m}$ in size and sporulated oocysts reached $13.3 \times 11.2 \mu \mathrm{m}$. Sporocysts, $6.58 \pm 0.75 \times 4.84 \pm 0.58(4.9-7.7 \times 4.2-5.6) \mu \mathrm{m}$ ( $\mathrm{n}=11$ ) in size, were still enclosed within oocysts or freely scattered, and contained either 2 deep-redstaining nuclei or already-developed sporozoites. In histological sections, only oocysts and sporocysts were

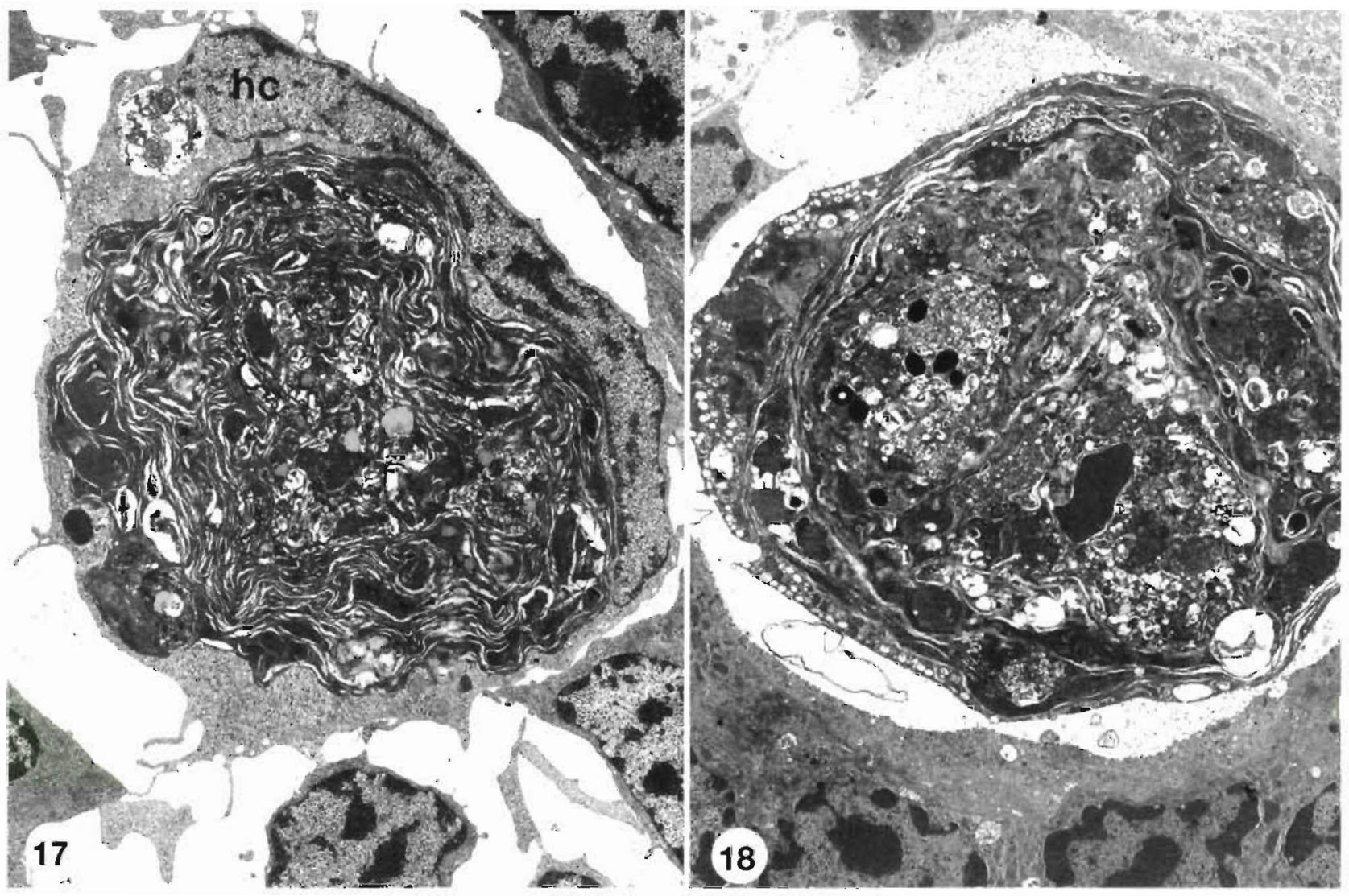

Figs. 17 \& 18. Yellow bodies within a detached cell of the gut epithelium of Hyperolis viridiflavus tadpoles. hc: intact host cell cytoplasm and an elongate nucleus $(\times 4700 \& \times 5300)$ 

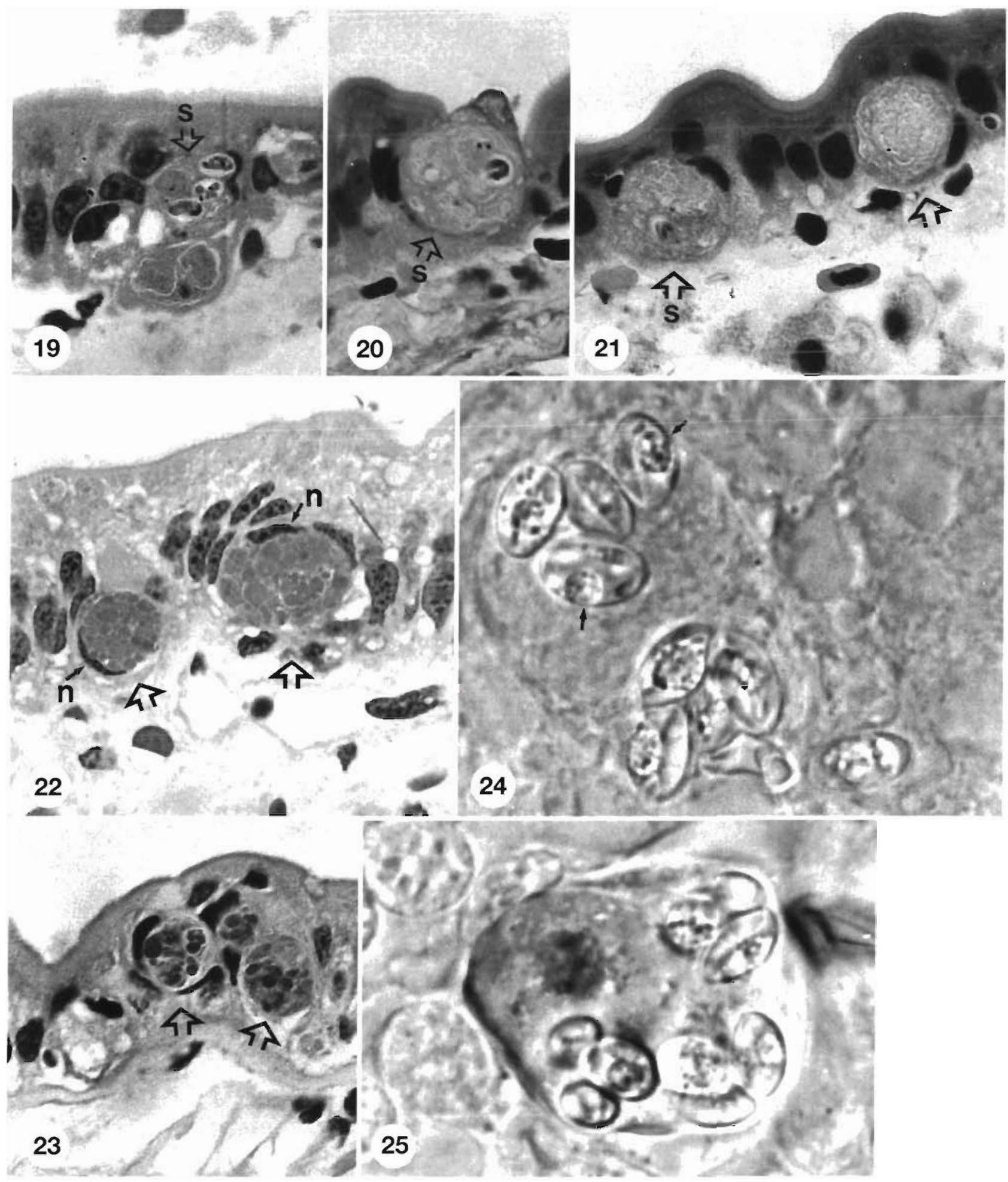

Figs. 19 to 23. MHE-stained histological sections of Goussia hyperolisi n. sp. infected Hyperolis viridiflavus tadpole gut $(\times 1420)$. Fig. 19. Sporulated oocyst (s) in gut tissue. Figs. 20 \& 21. Early yellow bodies (arrows), some still containing remains of sporocysts (s). Fig. 22. Yellow bodies filling up with the lipofuscin-like substance; the yellow-body cell nucleus is still noticeable (n). Fig. 23. Late (?) yellow body with dense granulated yellow substance.

Figs. $24 \& 25$. Sporulated oocysts of $G$. hyperolisi $n$. sp. in fresh squash preparation from $H$. viridiflavus intestine $(\times 2460)$ 


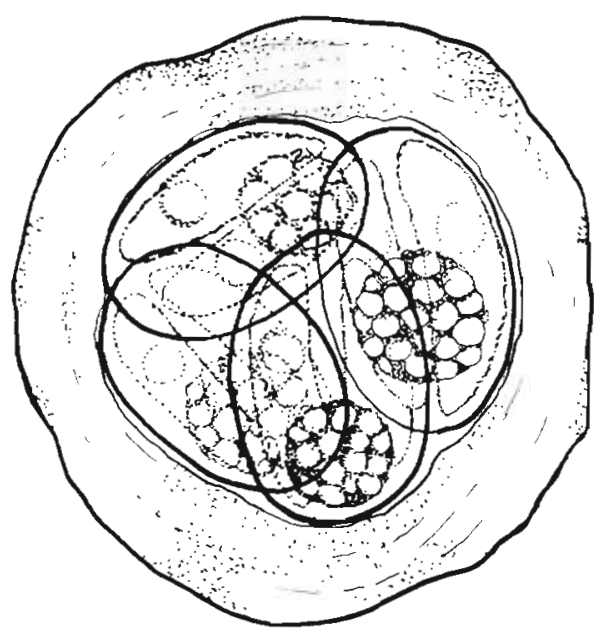

Fig. 26. Line drawing of sporulated oocyst enclosed within a yellow body $(\times 4700)$

found in the gut tissue, predominantly in the epithelial layer. Usually several sporulated oocysts (up to 8) or freed sporocysts were seen aggregating in an inclusion of degenerate substance inside hypertrophied host cells (Figs. 19 to 21, $24 \& 25$ ). A few sporulated oocysts, however, were seen lodged inside the underlying mucosal connective tissue (lamina propria). Yellow bodies remained after the infection had terminated (Figs. 20 \& 21). In Giemsa-stained smears these bodies reached a diameter of $15 \mu \mathrm{m}$, had a coagulated consistency and stained violet gray.

\section{Remarks}

This is the first described eimeriid species from African-continent anurans (see Upton \& McAllister 1988). Sporocysts of the presently described species from African reed frog tadpoles open via longitudinal sutures, which is a characteristic of members of the genus Goussia. The coccidium is very similar to $G$. neglecta (Nöller 1920) redescribed by Molnar (1995) from Rana rhidibunda and $R$. esculenta tadpoles in Hungary. Sizes of the oocysts and sporocyst of the presently reported species diverge somewhat from those of $G$. neglecta, with a sporocyst shape index of $1.1-1.3$ versus 1.8 in the latter. Furthermore, conspecificity on account of geographical and host (at the generic level) differences seems to be unlikely.

\section{DISCUSSION}

Infections by Coussia spp. seem to be widespread among tadpoles of diverse genera. Lee Berger of the CSIRO Australian Animal Health Laboratory, Geelong,
Victoria, Australia, presented the senior author with a histological slide prepared from the intestine of a Lymnodynastes tasmanicus tadpole heavily infected with sporulating Goussia-like coccidian oocysts, similar to the one presently described. Molnar (1995) pointed out the close relationship between G. neglecta and congeneric species infecting fish, and associated them with the aquatic nature of their hosts, as compared to the terrestrial habitat of frogs and toads. A close affinity to piscine species is not restricted, however, to tadpole coccidia: Coccidia occurring in metamorphosed frogs and toads also have a thin, fragile oocyst wall, sporocysts lacking a stieda body (though some do open through an apical device, rather than a longitudinal suture; Chen \& Desser 1989) and show endogenous sporulation, which takes place inside the gut epithelium (Paperna 1995a, Paperna \& Lainson 1995). Similar to the previously described Eimeria bufomarini, from Bufo marinus (Paperna \& Lainson 1995), and to piscine coccidia (Paperna 1995b), wall-forming bodies, as they occur among reptilian, avian and mammalian coccidia (Scholtyseck 1979, Ostrovska \& Paperna 1987), are lacking. In this context it is also worth noting the observed merging of the oocyst envelope with the PV wall, which recalls the process of oocyst wall formation in several piscine coccidia (Desser \& Li 1984, Paperna $1995 \mathrm{~b})$

Of the few other fine structural characteristics observed which are absent from the previously described anuran Coccidia, adnuclear inclusions have been reported in some reptilian coccidia (Ostrovska \& Paperna 1987); the tube-like structure apparently connecting rhoptries to the apical complex in merozoites and sporozoites has also been observed in hemogregarine merozoites (Paperna \& Sabnai 1982) and Sarcocystis bradyzoites (Paperna unpubl. data). Peculiar to the presently described coccidium were the intense folding of the PV wall and the large size of the rhoptries.

While describing Goussia neglecta, Nöller (1920) noted the disappearance of infection from the tadpoles as they neared their metamorphosis to frogs. In the reed frog, infection also terminated in tadpoles which failed to develop to the metamorphosis stage. This suggests that infection is time-restricted and expires independently of the metamorphosis process. It is worth noting that, unlike in pond conditions, in laboratorykept tadpoles reinfection is less likely to occur. It remains to be seen, however, whether the parasite can become established and develop in gut cells of frogs The host cells of oocyst stages in the tadpoles resemble intraepithelial leukocytes rather than ordinary mucosal epithelial cells. This is suggested from their elongate nuclei and the processes extending from their surface, which is often disengaged from the neighboring cells. Intraepithelial lymphocytes (IELs) have been 
shown to be the host cells of invading sporozoites and possibly other stages as well (Lawn \& Rose 1982, Fernando et al. 1987, Vilenkin \& Paperna 1997). The infected host cells in the tadpole gut seemed to become surrounded by additional intraepithelial leukocytes. The spontaneous termination of the infection suggests the involvement of defense processes. It is highly reminiscent of the spontaneous recovery phenomena involving a formation of 'yellow bodies' reported in infections by the piscine coccidia $G$. carpelli (Kent \& Hedrick 1985, Jendrysek et al. 1994) and G. sinensis (Baska \& Molnar 1989). Although yellow bodies occur in guts of fish not infected with Coccidia, in tadpoles, as in fish, their appearance seems to be linked with the final stage of the coccidial infection in the host cells (Moinar 1984, Lom et al. 1991). The presence of several oocysts in such bodies is the consequence of multiple infection rather than of the merging of several host cells as suggested previously (Lom et al. 1991). In $G$. carpelli infections, yellow bodies interfere with the release process of ripe sporocysts into the gut lumen, and hence their evacuation from their host (M. Vilenkin \& Paperna unpubl.). In tadpoles, as in fish, sporulated oocysts locked within the formed yellow body gradually disintegrate.

Kent \& Hedrick (1985) demonstrated ceroid and lipofuscin in yellow bodies of Goussia carpelli, while electron microscopic images of yellow bodies revealed electron-dense, degenerating membranes, connected with secondary lysosomes. Multilaminated structures and lysosomal electron-dense inclusions also occurred in the tadpole yellow body. The globular lipofuscine seen in the tadpole gut yellow bodies under light microscope seem to have been extracted during processing for electron microscopy. Migration or displacement of coccidial oocysts or other stages below the gut mucosal basal lamina is a common phenomenon among coccidia of fish (Molnar 1984) as well as of other vertebrates (Pasternak \& Fernando 1984).

Acknowledgements. The authors thank Mrs G. Rotish of the Museum of Kenya for the identification of the frogs and Prof. E. S. Mitema, head of the Department of Public Health, Pharmacology and Toxicology, Faculty of Veterinary Medicine, University of Nairobi, for providing research facilities to the first author This work was partially supported by a research grant to the first author from the Israeli Ministry of Science.

\section{LITERATURE CITED}

Baska F, Molnar K (1989) Ultrastructural observations on different developmental stages of Goussia sinensis (Chen, 1955) a parasite of the silver carp (Hypophthalmichthys molitrix Valenciennes, 1844) Acta Vet Hung 37:81-87

Editorial responsibility: Wolfgang Körting,

Hannover, Germany
Chen GJ, Desser SS (1989) The Coccidia (Apicomplexa Eimeriidae) of frogs from Algonquin Park, with description of two new species. Can J Zool 67:1686-1689

Desser SS, Li L (1984) Ultrastructural observations on the sexual stages and oocyst formation in Eimeria laureleus (Protozoa, Coccidia) of perch, Perca flavescens from Lake Sasajewum, Ontario. Z Parasitenkd 70:153-164

Fernando MA, Rose E, Millard BJ (1987) Eimeria spp. of domestic fowl: the migration of sporozoites intra- and extra-enterically. J Parasitol 73:561-567

Jenndrysek S, Steinhagen D, Drommer W, Korting W (1994) Carp coccidiosis: intestinal histo- and cytopathology under Goussia carpelli infection. Dis Aquat Org 20:171-182

Kent ML, Hedrick RP (1985) The biology and associated pathology of Goussia carpelli (Leger and Stankovich) in goldfish Carassius auratus (Linnaeus). Fish Pathol 20: 485-494

Laveran MA, Mesnil F (1902) Sur deux corcidies intestinales de la Rana esculenta. C R Soc Biologique 54:857-860

Lawn AM, Rose MA (1982) Mucosal transport of Eimeria tenella in the cecum of the chicken. J Parasitol 68: $1117-1123$

Lom J, Steinhagen D, Körting W, Dykova I (1991) Oocyst formation in the coccidian parasite Goussia carpelli. Dis Aquat Org 10:203-209

Molnar K (1984) Some peculiarities of oocyst rejection of fish coccidia. Symp Biol Hung 23:87-97

Molnar K (1995) Redescription of Goussia neglecta n. comb. (Nöller, 1920) (Apicomplexa; Coccidia) and notes on its occurrence in the gut of tadpoles. Acta Vet Hung 43: 269-275

Nöller W (1920) Zur Kenntnis der Coccidien des Wasserfrosches (Eimeria neglecta nov. spec.) (Befruchtung und Sporogonie von Lankesterella). Arch Protistenkd 41:176-180

Ostrovska K, Paperna I (1987) Fine structure of gamont stages of Schellackia cf. agamae (Lankesterellidae, Eucoccidia) from the starred lizard Agama stellio. Parasitol Res 73 $492-499$

Paperna I (1995a) Coccidiosis in anurans. In: Zwart P, Matz G (eds) Herpetologia. Proceedings Fifth International Colloquium on the Pathology of Reptiles and Amphibians, March 31-April 2, 1995. NRG Repro Facility BV's-Hertogenbosch Pays Bas, Alpen Aan den Rijn, The Netherlands, p $81-82$

Paperna I (1995b) Ultrastructure and developmental affinities of piscine coccidia. Dis Aquat Org 22:67-76

Paperna I, Lainson R (1995) Life history and ultrastructure of Eimeria bufomarini n. sp. (Apicomplexa: Eimeriidae) of the giant toad, Bufo marinus (Amphibia: Anura) from Amazonian Brazil. Parasite 2:141-148

Paperna I, Sabnai I (1982) A coccidium cyst stage in musculature of Liza subviridis (Mugilidae). Z Parasitenkd 68: 161-170

Pasternak J, Fernando MA (1984) Host cell response to coccidian infection: an introspecive survey. Parasitol 88: 555-563

Scholtyseck E (1979) Fine structure of parasitic Protozoa. Springer, Berlin, p 206

Upton SJ, McAllister CT (1988) The Coccidia (Apicomplexa: Eimeriidae) of Anura, with description of four new species. Can J Zool 66:1822-1830

Vilenkin M. Paperna I (1997) Initial development of sporozoites of the piscine coccidium Eimeria (sensu lato) vanasi in gut intraepithelial lymphocyte-like cells. Folia Parasitol 44:91-98

Submitted: February 2, 1997; Accepted: August 11, 1997 Proofs received from author(s): November 3, 1997 